\title{
DIAGNOSA PENYAKIT SALURAN PERNAPASAN DENGAN MENGGUNAKAN SUPPORT VECTOR MACHINE (SVM)
}

\author{
Zeth A. Leleury', Berny P. Tomasouw ${ }^{2}$ \\ 1,2Jurusan Matematika FMIPA Universitas Pattimura \\ Jl. Ir. M. Putuhena, Kampus Unpatti, Poka-Ambon, Indonesia \\ e-mail: ${ }^{2}$ peboberny@gmail.com
}

\begin{abstract}
Abstrak
Support Vector Machine (SVM) telah banyak digunakan untuk membantu menyelesaikan berbagai macam permasalahan dalam rangka pengambilan keputusan berdasarkan pelatihan yang diberikan. Aplikasi SVM dapat diterapkan dalam berbagai bidang, salah satunya dalam bidang kesehatan. Dalam penelitian ini, aplikasi SVM digunakan untuk mendiagnosa penyakit saluran pernapasa khususnya pada penyakit Tuberculosis, Asma, Sinusitis, Bronchitis, Pneumonia, dan ISPA berdasarkan gejala-gejala dari penyakit saluran pernapasan tersebut. Data yang digunakan dalam penelitian ini sebanyak 77 data, 56 data untuk pelatihan dan 21 data untuk pengujian. Data di atas diperoleh dari ruang rekam medis RSUD Dr. M. Haulussy Ambon. Dalam penelitian ini, diujicobakan variasi fungsi kernel pada SVM untuk mendapatkan tingkat keakuratan yang terbaik. Tingkat keakuratan terbaik dari pengujian 21 data diperoleh sebesar $80.95 \%$.
\end{abstract}

Kata Kunci: Penyakit saluran pernapasan, SVM.

\section{A DIAGNOSE OF SOME RESPIRATORY DISEASES USING SUPPORT VECTOR MACHINE (SVM)}

\begin{abstract}
Support Vector Machine (SVM) has been widely used to solve various problems in the context of decision making based on the training provided. SVM application can be applied in various fields, one of them is in the health field. In this study, application of SVM is used to diagnose diseases of respiratory tract, especially in Tuberculosis, Asthma, Sinusitis, Bronchitis, Pneumonia, and ISPA diseases based on the symptoms of the respiratory disease. The data used in this study as many as 77 data, the data for the 56 training and 21 data for testing. The above data was obtained from medical records space Hospital Dr. M. Haulussy Ambon. In this study, variations on SVM kernel functions is tested to get the best accuracy. Best accuracy rate of 21 testing data is obtained by $80.95 \%$.
\end{abstract}

Keywords: Respiratory disease, SVM.

\section{Pendahuluan}

Support Vector Machine (SVM) dikembangkan oleh Boser, Guyon, Vapnik, dan pertama kali dipresentasikan pada tahun 1992 di Annual Workshop on Computational Learning Theory. Konsep dasar SVM bermula dari masalah klasifikasi dua kelas yang tergolong dalam masalah linier (linear problem). SVM berusaha menemukan hyperplane (pemisah) terbaik pada input space untuk memisahkan dua klas tersebut. Selanjutnya SVM dikembangkan agar dapat bekerja pada masalah non-linear, dengan memasukkan konsep fungsi pada ruang kerja berdimensi tinggi.

Dalam mencari hyperplane terbaik, SVM akan dihadapkan pada proses mencari solusi dari masalah pemrograman kuadratik. Masalah pemrograman kuadratik sendiri dapat berupa bentuk primal dan bentuk dual. Pada umumnya penelitian yang dikembangkan cenderung memilih menyelesaikan bentuk dual ketimbang bentuk primal karena dianggap lebih mudah. Selain itu performa SVM akan menjadi lebih baik jika dipilih fungsi kernel yang tepat. Dalam bukunya yang berjudul "Support Vector Machines for Pattern Classification", 
Abe [1] menjelaskan cara menerapkan fungsi kernel dan cara menyelesaikan masalah pengenalan pola dengan banyak kelas (multi-class) dengan menggunakan SVM.

\subsection{Sistem Pernapasan pada Manusia}

Sistem pernapasan pada manusia adalah sistem menghirup oksigen dari udara serta mengeluarkan karbon dioksida dan uap air [2]. Dalam proses pernapasan, oksigen merupakan zat kebutuhan utama. Oksigen untuk pernapasan diperoleh dari udara di lingkungan sekitar. Alat-alat pernapasan berfungsi memasukan udara yang mengandung oksigen dan mengeluarkan udara yang mengandung karbon dioksida dan uap air. Tujuan proses pernapasan yaitu untuk memperoleh energi. Pada peristiwa bernapas terjadi pelepasan energi. Sistem pernapasan pada manusia mencakup dua hal, yakni saluran pernapasan dan mekanisme pernapasan.

Saluran pernapasan adalah bagian tubuh manusia yang berfungsi sebagai tempat pertukaran gas yang diperlukan untuk proses pernapasan. Saluran ini berpangkal pada hidung, tekak (faring), tenggorokan (trakea), cabang tenggorokan (bronkus), bronkiolus, alveolus, dan berakhir pada paru-paru. Namun, dalam organ-organ tersebut dapat mengalami gangguan. Gangguan ini biasanya berupa kelainan, penyakit, atau karena ulah manusia itu sendiri (seperti merokok). Penyakit atau gangguan yang menyerang sistem pernapasan ini dapat menyebabkan terganggunya proses pernapasan. Adapun penyakit yang bisa terjadi pada saluran pernapasan berdasarkan beberapa askep keperawatan yaitu:

a. Tuberkulosis

Tuberkulosis (TBC) merupakan infeksi pada paru-paru yang disebabkan oleh bakteri Mycobacterium tuberculosis. Infeksi biasanya terjadi di bagian atas paru-paru. Gejala Tuberkulosis antara lain:

1) Kelelahan;

2) Kehilangan berat badan;

3) Berkeringat pada malam hari.

Jika infeksi lebih buruk, Gejala Tuberkulosis yang akan timbul yaitu:

1) Dada sakit;

2) Batuk dengan mengeluarkan dahak atau darah;

3) Napas pendek atau sesak nafas.

b. Asma

Asma adalah gangguan pada organ pernapasan berupa penyempitan saluran pernapasan akibat reaksi terhadap suatu rangsangan tertentu. Gejala-gejala awal dari serangan asma yaitu:

1) Perubahan dalam pola pernapasan;

2) Bersin-bersin;

3) Perubahan suasana hati;

4) Hidung mampat;

5) Batuk;

6) Gatal-gatal pada tenggorokan;

7) Sering merasa capek;

8) Lingkaran hitam di bawah mata;

9) Susah tidur;

10) Turunnya toleransi tubuh terhadap kegiatan olahraga.

Gejala-gejala asma akut memberi indikasi bahwa suatu serangan asma sedang terjadi. Gejalanya meliputi:

1) Napas berat;

2) Batuk-batuk;

3) Napas pendek tersengal-sengal;

4) Sesak dada;

Hal-hal di atas menunjukkan bahwa perubahan telah terjadi pada saluran pernapasan dan aliran udara terhambat. Penderita asma mengalami beberapa atau semua gejala di atas pada suatu serangan.

c. Sinusitis

Sinusitis merupakan peradangan yang terjadi pada organ sinus. Sinus sendiri adalah rongga udara yang terdapat didaerah wajah yang langsung terhubung dengan hidung. Peradangan pada sinus ini dapat menyebabkan penimbunan lendir pada rongga sinus dan menjadi media bagi pertumbuhan bakteri.

Gejala-gejala yang ditimbulkan penyakit ini adalah:

1) Sakit atau nyeri pada wajah dan dahi; 
2) Ingus keluar dari hidung berwarna kuning atau hijau serta berbau tajam;

3) Hidung tersumbat;

4) Berkurangnya daya pengecap;

5) Kepala yang terasa nyeri;

6) Batuk;

7) Sakit tenggorokan.

d. Bronkhitis

Penyakit bronkitis yang menyerang organ paru-paru yang merupakan organ tubuh yang sangat penting bagi kehidupan manusia yang merupakan penyedia udara (napas) bagi manusia, namun sering kali menuai gangguan penyakit yang umumnya diakibatkan oleh kesalahan individu itu sendiri, seperti merokok yang merupakan faktor utama dari kasus penyebab penyakit bronkitis dan penyakit seputar paru-paru yang banyak menyerang.

Bronkitis banyak diartikan oleh masyarakat umum sebagai penyakit sesak napas akut terutama bagi mereka yang aktif dalam rokok. Mereka yang menderita bronkitis umumnya akan menunjukkan gejala umum seperti:

1) Batuk berdahak (dahaknya bisa berwarna kemerahan);

2) Sesak napas ketika melakukan olahraga atau aktivitas ringan;

3) Sering menderita infeksi pernapasan (misalnya flu);

4) Napas berat;

5) Mudah lelah;

6) Pembengkakan di pergelangan kaki, kaki, dan tungkai kaki kiri dan kanan;

7) Wajah, telapak tangan atau selaput lendir yang berwarna kemerahan;

8) Pipi tampak kemerahan;

9) Sakit kepala;

10) Gangguan penglihatan.

e. Pneumonia

Pneumonia atau sering disebut paru-paru basah adalah infeksi atau peradangan pada salah satu atau kedua paru-paru, lebih tepatnya peradangan itu terjadi pada kantung udara. Kantung udara akan terisi cairan atau nanah, sehingga menyebabkan sesak nafas, batuk berdahak, demam, menggigil, dan kesulitan bernapas. Infeksi tersebut disebabkan oleh berbagai organisme, termasuk bakteri, virus dan jamur.

Tanda-tanda dan gejala pneumonia bervariasi mulai dari yang ringan hingga yang berat, tergantung pada faktor-faktor seperti jenis kuman penyebab, usia penderita dan kondisi kesehatan secara keseluruhan. Tanda-tanda dan gejala pneumonia yang ringan sering kali mirip dengan flu atau sakit demam dan batukpilek, namun tak kunjung sembuh atau bertahan lama.

Ciri-ciri dan gejala pneumonia antara lain:

1) Demam, berkeringat dan menggigil;

2) Suhu tubuh lebih rendah dari normal pada orang di atas usia 65 tahun, dan pada orang dengan sistem kekebalan tubuh yang lemah;

3) Batuk berdahak tebal dan kental (lengket);

4) Nyeri dada saat bernapas dalam atau ketika batuk;

5) Sesak napas (nafas cepat);

6) Kelelahan dan nyeri otot;

7) Mual, muntah atau diare;

8) Sakit kepala.

Ada banyak kemungkinan penyebab pneumonia, yang paling sering adalah karena infeksi bakteri dan virus dari udara yang kita hirup.

\section{f. Infeksi Saluran Pernapasan Atas (ISPA)}

Infeksi saluran pernapasan atas atau sering disebut sebagai ISPA adalah terjadinya infeksi yang parah pada bagian sinus, tenggorokan, saluran udara, atau paru-paru. Infeksi yang terjadi lebih sering disebabkan oleh virus meski bakteri juga bisa menyebabkan kondisi ini. 
ISPA akan menimbulkan gejala yang terutama terjadi pada hidung dan paru-paru. Beberapa gejalanya antara lain:

1) Hidung tersumbat atau berair;

2) Para-paru terasa terhambat;

3) Batuk-batuk dan tenggorokan terasa sakit;

4) Kerap merasa kelelahan;

5) Tubuh merasa sakit.

Apabila ISPA bertambah parah, gejala yang lebih serius akan muncul, seperti:

1) Kesulitan bernapas;

2) Demam tinggi dan menggigil;

3) Tingkat oksigen dalam darah rendah;

4) Kesadaran yang menurun dan bahkan pingsan.

\subsection{Support Vector Machine (SVM)}

a. SVM Linier

Misalkan terdapat $m$ data pelatihan $\left\{\left(x_{1}, y_{1}\right),\left(x_{2}, y_{2}\right), \ldots,\left(x_{m}, y_{m}\right)\right\}$ dimana $x_{i} \in \mathbb{R}^{n}$ adalah sampel data dan $y_{i} \in\{1,-1\}$ adalah target atau klas dari sampel data. Misalkan juga bahwa data untuk kedua kelas terpisah secara linier (linearly separable) maka ingin dicari fungsi pemisah (hyperplane)

$$
f(x)=x w+b=0,
$$

dimana $w \in \mathbb{R}^{n \times 1}$ adalah parameter bobot dan $b \in \mathbb{R}$ adalah parameter bias serta berlaku:

$$
\begin{aligned}
& x_{i} w+b>0 \text { untuk } y_{i}=1 \\
& x_{i} w+b<0 \text { untuk } y_{i}=-1
\end{aligned}
$$

Misalkan $H: x w+b=0$ adalah hyperplane yang ingin dicari sedangkan $H_{1}: x w+b=1$ dan $H_{2}: x w+b=-1$ adalah hyperplane dari kelas 1 dan kelas -1. Untuk mendapatkan $H$ yang optimal maka jarak $H_{1}$ dan $H_{2}$ ke $H$ haruslah sama dengan syarat bahwa tidak ada sampel data antara $H_{1}$ dan $H_{2}$ serta jarak $H_{1}$ ke $H_{2}$ adalah jarak yang maksimal. Untuk memaksimalkan jarak $H_{1}$ dan $H_{2}$ maka digunakan sampel data positif yang terletak pada $H_{1}$ dan sampel data negatif yang terletak pada $H_{2}$. Sampel data ini disebut support vector karena fungsinya sebagai penentu dalam mendapatkan hyperplane yang optimal.

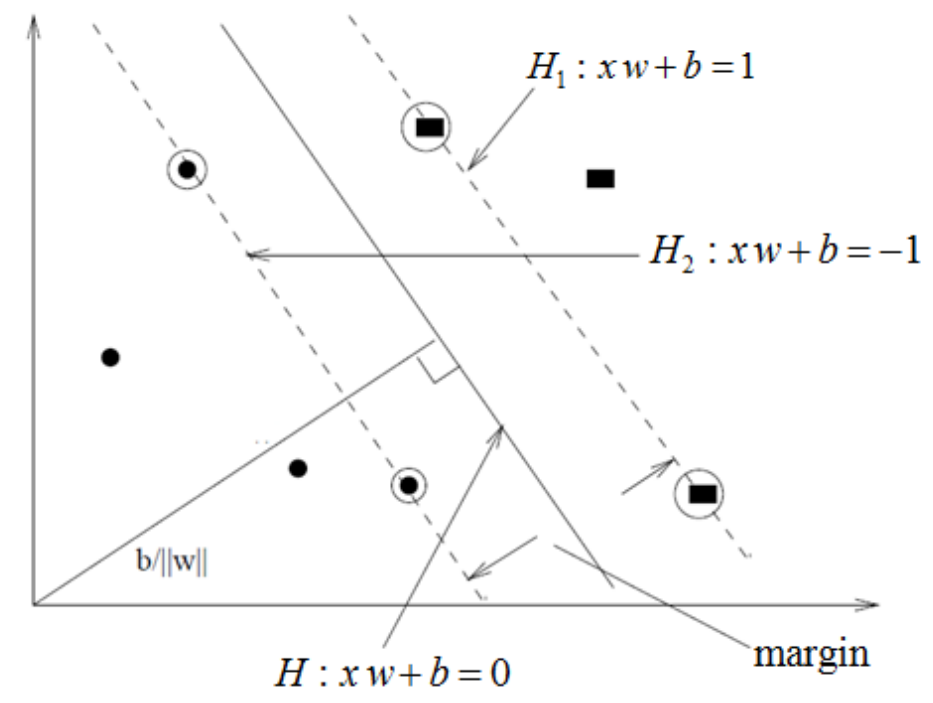

Gambar 1. Contoh Hyperplane Optimal yang Memisahkan 2 Kelas 
Masalah mencari parameter $w$ dan $b$ yang optimal agar diperoleh hyperplane yang optimal merupakan masalah pemrograman kuadratik

$$
\min _{w, b} \frac{1}{2} w^{T} w
$$

dengan kendala

$$
y_{i}\left(x_{i} w+b\right) \geq 1 \quad, \quad i=1, \cdots, m \text {. }
$$

Solusi dari masalah pemrograman kuadratik di atas didapatkan dengan cara mengubah bentuk primal ke bentuk dual dengan memperkenalkan pengali Lagrange. Misalkan $\alpha \in \mathbb{R}^{m \times 1}$ adalah pengali Lagrange maka masalah pemrograman kuadratik (1) di atas berubah menjadi

$$
L(w, b, \alpha)=\frac{1}{2} w^{T} w-\sum_{i=1}^{m} \alpha_{i}\left(y_{i}\left(x_{i} w+b\right)\right)+\sum_{i=1}^{m} \alpha_{i} .
$$

Solusi dari masalah ini harus memenuhi syarat Karush-Kuhn-Tucker (KKT) yakni:

i. $\quad \frac{\partial L}{\partial w}=0 \Rightarrow w-\sum_{i=1}^{m} \alpha_{i} y_{i} x_{i}=0$

$$
\Rightarrow w=\sum_{i=1}^{m} \alpha_{i} y_{i} x_{i}
$$

ii. $\frac{\partial L}{\partial b}=0 \Rightarrow 0-\sum_{i=1}^{m} \alpha_{i} y_{i}=0$

$$
\Rightarrow \sum_{i=1}^{m} \alpha_{i} y_{i}=0
$$

iii. $\quad \alpha_{i}\left(y_{i}\left(x_{i} w+b\right)-1\right)=0$;

iv. $\alpha_{i} \geq 0$.

Dengan demikian bentuk dual yang diperoleh adalah

$$
\operatorname{Max} L(\alpha)=\sum_{i=1}^{m} \alpha_{i}-\frac{1}{2} \sum_{i=j=1}^{m} \alpha_{i} \alpha_{j} y_{i} y_{j} x_{i} x_{j}^{T}
$$

dengan kendala

$$
\sum_{i=1}^{m} \alpha_{i} y_{i}=0 \quad \text { dan } \quad \alpha_{i} \geq 0 \text { dimana } i=1,2, \cdots, m .
$$

Parameter bobot dan bias dapat dihitung dengan persamaan

$$
w=\sum_{i=1}^{N_{s v}} \alpha_{i} y_{i} x_{i} \text { dan } \quad b=\frac{1}{N_{S V}} \sum_{i=1}^{N_{S V}}\left(y_{i}-x_{i} w\right) .
$$

$S V$ adalah himpunan support vector dan $i \in S V$ jika $\alpha_{i} \neq 0 . N_{S V}$ adalah jumlah support vector. Dengan menggunakan persamaan

$$
f(x)=x w+b
$$

maka data input $x \in \mathbb{R}^{n}$ yang baru diklasifikasikan menjadi

$$
\begin{cases}\text { klas }+1, & \text { jika } f(x)>0 \\ \text { klas }-1, & \text { jika } f(x)<0\end{cases}
$$


Selanjutnya jika terjadi kasus pemisahan yang tidak sempurna, dalam hal ini terdapat data antara $H_{1}$ dan $H_{2}$. Untuk mengatasi masalah ini, akan diperkenalkan variabel slack $\mu$ yang tak negatif $(\mu \geq 0)$ dan dimasukan pada fungsi kendala (1) sehingga menjadi

$$
y_{i}\left(x_{i} w+b\right) \geq 1-\mu_{i}, i=1,2, \cdots, m .
$$

Sedangkan pada fungsi objektifnya ditambahkan parameter positif $C$ sehingga menjadi

$$
\frac{1}{2} w^{T} w+C \sum_{i=1}^{m} \mu_{i}
$$

Secara lengkap, masalah pemrograman kuadratik (1) berubah menjadi

$$
\min _{w, b} \frac{1}{2} w^{T} w+C \sum_{i=1}^{m} \mu_{i}
$$

dengan kendala

$$
y_{i}\left(x_{i} w+b\right) \geq 1-\mu_{i}, \quad \mu_{i} \geq 0, i=1,2, \cdots, m .
$$

Dengan menggunakan pengali Lagrange $\alpha \in \mathbb{R}^{m \times 1}$ maka bentuk primal (5) dapat diubah menjadi bentuk dual sebagai berikut

$$
\operatorname{Max} L(\alpha)=\sum_{i=1}^{m} \alpha_{i}-\frac{1}{2} \sum_{i=j=1}^{m} \alpha_{i} \alpha_{j} y_{i} y_{j} x_{i} x_{j}^{T}
$$

dengan kendala

$$
\sum_{i=1}^{m} \alpha_{i} y_{i}=0 \text { dan } 0 \leq \alpha_{i} \leq C, i=1,2, \cdots, m
$$

\section{b. SVM Non-Linier}

Dalam masalah klasifikasi kebanyakan sampel data tidak terpisah secara linier sehingga jika digunakan SVM linier maka hasil yang diperoleh tidak optimal dan mengakibatkan hasil klasifikasi yang buruk. Yang menjadi salah satu keunggulan SVM terletak pada bagian ini, yakni SVM dapat diperluas untuk menyelesaikan masalah non-linier. SVM linier dapat diubah menjadi SVM non-linier dengan menggunakan metode kernel. Metode ini bekerja dengan cara memetakan data input ke ruang feature yang dimensinya lebih tinggi menggunakan fungsi sebuah $\phi$. Sebagai contoh, misalkan $u=\left(u_{1}, u_{2}\right)$ adalah data input pada $\mathbb{R}^{2}$ dan $\phi(u)=\left(1, \sqrt{2} u_{1}, \sqrt{2} u_{2}, u_{1}^{2}, u_{2}^{2}, \sqrt{u_{1}} u_{2}\right)$ adalah data input pada ruang feature yang berdimensi lebih tinggi yakni $\mathbb{R}^{5}$. Diharapkan data input hasil pemetaan ke ruang feature akan terpisah secara linier sehingga dapat dicari hyperplane yang optimal.

Misalkan $x \rightarrow \phi(x)$ maka Persamaan (6) dapat ditulis menjadi

$$
\operatorname{Max} \psi(\alpha)=\sum_{i=1}^{m} \alpha_{i}-\frac{1}{2} \sum_{i=j=1}^{m} \alpha_{i} \alpha_{j} y_{i} y_{j} \phi^{T}\left(x_{i}\right) \phi\left(x_{j}\right)
$$

dengan kendala

$$
\sum_{i=1}^{m} \alpha_{i} y_{i}=0 \quad \text { dan } \quad \alpha_{i} \geq 0 \text { dimana } i=1,2, \cdots, m
$$


Parameter bobot dan bias dapat dihitung dengan persamaan

$$
w=\sum_{i=1}^{N_{S V}} \alpha_{i} y_{i} \phi\left(x_{i}\right) \text { dan } b=\frac{1}{N_{S V}} \sum_{i=1}^{N_{S V}}\left(y_{i}-w^{T} \phi\left(x_{i}\right)\right) ;
$$

Sedangkan hyperplane optimal adalah

$$
f(x)=w^{T} \phi(x)+b=0 .
$$

Permasalahan yang muncul adalah jika sampel data input untuk tahap training dalam jumlah besar maka perhitungan hasil kali titik $\phi^{T}\left(x_{i}\right) \phi\left(x_{j}\right)$ pada (7) akan membuat waktu perhitungan semakin lama. Oleh karena itu diperlukan cara untuk menghitung $\phi^{T}\left(x_{i}\right) \phi\left(x_{j}\right)$ tanpa mengetahui fungsi $\phi$.

Misalkan $K$ adalah sebuah fungsi dengan sifat

$$
K(u, v)=\phi^{T}(u) \phi(v)
$$

dimana $u, v \in \mathbb{R}^{n}$ dan $\phi: \mathbb{R}^{n} \rightarrow \mathbb{R}^{m}, n<m$. Fungsi $K$ ini disebut sebagai fungsi kernel. Menurut Shigeo Abe [1] fungsi kernel yang sering digunakan adalah sebagai berikut:

1) Kernel linier: $K(u, v)=u^{T} v$.

2) Kernel polinomial: $K(u, v)=\left(1+u^{T} v\right)^{d}, d \geq 2$.

3) Kernel RBF (Radial Basis Function): $K(u, v)=\exp \left(-\gamma\|u-v\|^{2}\right), \gamma>0$.

Dengan menggunakan konsep fungsi kernel di atas maka Persamaan (7)-(9) berubah menjadi

$$
\operatorname{Max} \psi(\alpha)=\sum_{i=1}^{m} \alpha_{i}-\frac{1}{2} \sum_{i=j=1}^{m} \alpha_{i} \alpha_{j} y_{i} y_{j} K\left(x_{i}, x_{j}\right)
$$

dengan kendala

$$
\sum_{i=1}^{m} \alpha_{i} y_{i}=0 \quad \text { dan } \quad \alpha_{i} \geq 0 \text { dimana } i=1,2, \cdots, m
$$

Parameter bias dapat dihitung dengan persamaan

$$
b=\frac{1}{N_{S V}} \sum_{i=1}^{N_{S V}}\left(y_{i}-\sum_{i=1}^{N_{S V}} \alpha_{i} y_{i} K\left(x_{i}, x_{j}\right)\right)
$$

sedangkan hyperplane optimalnya

$$
f(x)=\sum_{i=1}^{N_{S V}} \alpha_{i} y_{i} K\left(x_{i}, x\right)+b .
$$

Data input $x \in \mathbb{R}^{n}$ yang baru tetap diklasifikasikan berdasarkan syarat pada (4).

\section{c. Multi-class SVM}

Baik SVM linier maupun SVM non-linier yang telah dibahas di atas hanya dapat dipakai dalam menyelesaikan masalah klasifikasi dua kelas. Namun kenyataanya bahwa seringkali yang dihadapi adalah masalah klasifikasi multi-class. Metode Pairwise diterapkan pada SVM sehingga dapat menyelesaikan masalah klasifikasi multikelas.

\section{d. SVM berbasis Pairwise}

Misalkan terdapat $N$ jumlah kelas dari sampel data yang akan diklasifikasi. Metode Pairwise bekerja dengan cara membentuk semua kombinasi pasangan dua kelas yakni sebanyak $N(N-1) / 2$ dimana $N>2$. Oleh 
karena itu, metode ini juga seringkali disebut sebagai metode satu lawan satu (one against one). Misalkan hyperplane optimal yang diperoleh dari kelas $i$ dan kelas $j$ adalah

$$
f_{i j}(x)=w_{i j}^{T} \phi(x)+b_{i j}
$$

dimana $i=1,2, \ldots, N-1$ dan $j=i+1, i+2, \ldots, N$ serta berlaku $f_{j i}(x)=-f_{i j}(x)$. Data input $x \in \mathbb{R}^{n}$ yang baru akan diklasifikasikan berdasarkan hasil voting yang dihitung dengan rumus

$$
f_{i}(x)=\sum_{j \neq i, j=1}^{N} \operatorname{sgn}\left(f_{i j}(x)\right), \quad i=1,2, \cdots, N .
$$

dimana

$$
\operatorname{sgn}(u)= \begin{cases}1, & \text { jika } u \geq 0 \\ -1, & \text { jika } u<0\end{cases}
$$

Kelas ke-i yang memiliki nilai $f_{i}$ maksimum yang akan menjadi pemenang dan data input $x$ akan ditetapkan sebagai anggota kelas ke-i,

$$
\arg \max _{i=1,2, \ldots, N} f_{i}(x)
$$

Algoritma metode Pairwise secara ringkas adalah sebagai berikut:

1) Dapatkan hyperplane optimal yakni Persamaan (12) untuk semua kombinasi pasangan dua kelas.

2) Untuk data input $x$ yang baru hitung nilai $f_{i}(x), i=1,2, \ldots, N$ berdasarkan Persamaan (13) dan (14).

3) Data input $x$ diklasifikasikan menggunakan Persamaan (15).

\section{Hasil dan Pembahasan}

\subsection{Variabel Yang Digunakan}

Berdasarkan gejala klinisnya, penyakit saluran pernapasan yaitu Tuberculosis, Asma, Sinusitis, Bronchitis, Pneumonia, dan ISPA memiliki 16 gejala yang selanjutnya menjadi variabel input pada jaringan saraf tiruan. Gejala-gejala tersebut adalah batuk, sesak nafas, nyeri dada, mual dan muntah, demam, nyeri kepala, nyeri ulu hati, menggigil, berkeringat dingin, susah tidur, pilek, keluar secret/ingus, mudah lelah, kekakuan sendi, lidah berjamur dan hidung tersumbat.

Data-data yang diproses tersebut diambil secara acak, mulai dari anak-anak sampai dewasa pada tahun 2013 sampai dengan tahun 2015. Jumlah data sebanyak 77, dimana digunakan 56 data untuk pelatihan, dan 21 data untuk pengujian keakuratan sistem yang digunakan untuk mengenali pola masukan.

Agar data dapat dikenali oleh SVM, maka data harus diubah kedalam bentuk numerik, baik variabel maupun isinya, yaitu: 
Tabel 1. Gejala Penyakit dan Nilainya [3]

\begin{tabular}{|c|c|c|}
\hline Gejala-gejala & Variabel & Nilai \\
\hline \multirow{4}{*}{ Batuk $\left(X_{1}\right)$} & Tidak & 0 \\
\hline & Kering & 0.25 \\
\hline & Berdahak & 0.5 \\
\hline & Berdahak berdarah & 1 \\
\hline \multirow{3}{*}{ Sesak Nafas $\left(X_{2}\right)$} & Tidak & 0 \\
\hline & Jarang terjadi & 0.5 \\
\hline & Terus menerus & 1 \\
\hline \multirow{3}{*}{ Nyeri Dada $\left(X_{3}\right)$} & Tidak & 0 \\
\hline & Jarang terjadi & 0.5 \\
\hline & Sering Terjadi & 1 \\
\hline \multirow{4}{*}{ Mual dan Muntah $\left(X_{4}\right)$} & Tidak & 0 \\
\hline & Mual & 0.25 \\
\hline & Muntah & 0.5 \\
\hline & Mual dan muntah & 1 \\
\hline \multirow[t]{3}{*}{$\operatorname{Demam}\left(X_{5}\right)$} & Tidak & 0 \\
\hline & Jarang terjadi & 0.5 \\
\hline & Sering Terjadi & 1 \\
\hline \multirow{2}{*}{ Nyeri Kepala $\left(X_{6}\right)$} & Tidak & 0 \\
\hline & $\mathrm{Ya}$ & 1 \\
\hline \multirow[b]{2}{*}{ Nyeri Ulu Hati $\left(X_{7}\right)$} & Tidak & 0 \\
\hline & $\mathrm{Ya}$ & 1 \\
\hline \multirow{2}{*}{ Menggigil $\left(X_{8}\right)$} & Tidak & 0 \\
\hline & $\mathrm{Ya}$ & 1 \\
\hline \multirow{3}{*}{$\begin{array}{l}\text { Berkeringat Dingin } \\
\left(X_{9}\right)\end{array}$} & Tidak & 0 \\
\hline & Sering & 0.5 \\
\hline & Sering pada malam hari & 1 \\
\hline \multirow[t]{2}{*}{ Susah Tidur $\left(X_{10}\right)$} & Tidak & 0 \\
\hline & $\mathrm{Ya}$ & 1 \\
\hline \multirow{2}{*}{ Pilek $\left(X_{11}\right)$} & Tidak & 0 \\
\hline & $\mathrm{Ya}$ & 1 \\
\hline \multirow{3}{*}{$\begin{array}{l}\text { Keluar Sekret/ingus } \\
\left(X_{12}\right)\end{array}$} & Tidak & 0 \\
\hline & $\mathrm{Ya}$ & 0.5 \\
\hline & Ya dan berbau & 1 \\
\hline \multirow{2}{*}{ Mudah Lelah $\left(X_{13}\right)$} & Tidak & 0 \\
\hline & $\mathrm{Ya}$ & 1 \\
\hline \multirow{2}{*}{ Kekakuan Sendi $\left(X_{14}\right)$} & Tidak & 0 \\
\hline & $\mathrm{Ya}$ & 1 \\
\hline \multirow{2}{*}{ Lidah Berjamur $\left(X_{15}\right)$} & Tidak & 0 \\
\hline & $\mathrm{Ya}$ & 1 \\
\hline \multirow{3}{*}{$\begin{array}{l}\text { Nyeri pada Hidung } \\
\left(X_{16}\right)\end{array}$} & Tidak & 0 \\
\hline & $\mathrm{Ya}$ & 0.5 \\
\hline & Ya dan terasa nyeri & 1 \\
\hline
\end{tabular}

Sedangkan rancangan penetapan keluaran (output) adalah:

1) Diberi nilai " 1 " untuk pasien yang didiagnosa penyakit tuberculosis.

2) Diberi nilai " 2 " untuk pasien yang didiagnosa penyakit asma.

3) Diberi nilai "3" untuk pasien yang didiagnosa penyakit sinusitis.

4) Diberi nilai "4" untuk pasien yang didiagnosa penyakit bronchitis.

5) Diberi nilai "5" untuk pasien yang didiagnosa penyakit pneumonia.

6) Diberi nilai "6" untuk pasien yang didiagnosa penyakit ISPA. 


\subsection{Hasil Penelitian}

Dalam penelitian ini diasumsikan bahwa data gejala penyakit yang digunakan sebagai input tidak linier sehingga metode yang digunakan adalah SVM non-linier. Pada tahap pelatihan akan diujicobakan variasi fungsi kernel sehingga bisa dipilih fungsi kernel yang memberikan hasil terbaik. Fungsi kernel inilah yang selanjutnya akan digunakan dalam sistem diagnosa.

Data pada tahap pelatihan akan digunakan lagi sebagai data tahap pengujian sehingga bisa dilihat fungsi kernel yang memberikan hasil terbaik. Tabel berikut memperlihatkan hasil pelatihan dengan variasi fungsi kernel.

Tabel 2. Perbandingan Hasil Pelatihan

\begin{tabular}{|l|c|}
\hline \multicolumn{1}{|c|}{ Fungsi Kernel } & Tingkat Akurasi \\
\hline Kernel Linier & $91.07 \%$ \\
\hline Kernel Polinomial & $90.03 \%$ \\
\hline Kernel RBF & $90.07 \%$ \\
\hline
\end{tabular}

Pada tabel di atas, terlihat bahwa fungsi kernel yang memberikan hasil terbaik adalah kernel linier dengan tingkat keakuratan $91.07 \%$.

Selanjutnya, hyperplane yang diperoleh dari fungsi kernel linier akan digunakan dalam tahap pengujian. Hasil tahap pengujian dari 21 data dapat dilihat dalam tabel berikut.

Tabel 3. Hasil Tahap Pengujian

\begin{tabular}{|c|c|c|}
\hline Pasien & Kelas & Hasil Pengujian \\
\hline 1 & 1 & 1 \\
\hline 2 & 1 & 1 \\
\hline 3 & 1 & 1 \\
\hline 4 & 1 & 1 \\
\hline 5 & 1 & 1 \\
\hline 6 & 1 & 1 \\
\hline 7 & 1 & 1 \\
\hline 8 & 1 & 1 \\
\hline 9 & 2 & 2 \\
\hline 10 & 2 & 4 \\
\hline 11 & 2 & 2 \\
\hline 12 & 2 & 2 \\
\hline 13 & 2 & 2 \\
\hline 14 & 2 & 1 \\
\hline 15 & 3 & 3 \\
\hline 16 & 4 & 4 \\
\hline 17 & 4 & 1 \\
\hline 18 & 5 & 5 \\
\hline 19 & 5 & 4 \\
\hline 20 & 6 & 4 \\
\hline 21 & 6 & 6 \\
\hline
\end{tabular}

Berdasarkan tabel di atas, dapat dilihat bahwa dari 21 data testing diperoleh hasil yaitu 17 pasien memiliki karakter yang dapat dikenali atau diagnosa dengan menggunakan program sama dengan hasil diagnosa dari dokter dan 4 pasien (pasien ke-10,14,17,19 dan 20) yang tidak sesuai. Pasien ke-10 memiliki diagnosa penyakit Asma, namun setelah dilakukan proses diagnosa menggunakan program, pasien tersebut didiagnosa memiliki penyakit Bronchitis. Sehingga dapat disimpulkan bahwa tingkat keberhasilan metode SVM dengan fungsi kernel linier untuk dapat mengenali pola dengan benar sebesar $80.95 \%$. 


\section{Kesimpulan}

Berdasarkan hasil penelitian maka dapat disimpulkan bahwa sistem yang dibuat mampu untuk mendiagnosa penyakit saluran pernapasan secara optimal dengan dengan fungsi Kernel Linier serta diperoleh tingkat keberhasilan pengujian pelatihan sebesar $80,95 \%$.

\section{Daftar Pustaka}

[1] S. Abe, Support Vector Machines for Pattern Classification, Second penyunt., London: Springer-Verlag, 2010.

[2] H. Sasrawan, "Kehidupan Awal Masyarakat Indonesia," 2 Januari $2013 . \quad$ [Online]. Available: http://hedisasrawan.blogspot.co.id/2013/01/kehidupan-awal-masyarakat-indonesia.html?m=1. [Diakses 5 November 2015].

[3] N. I. Pradasari, F. T. P. W. dan D. Triyanto, "Aplikasi Jaringan Saraf Tiruan untuk memprediksi Penyakit Saluran Pernapasan dengan Metode Backpropagation,” Jurnal Coding Sistem Komputer Untan, vol. 1, no. 1, 2013.

[4] L. Fausett, Fundamentals of Neural Network: Architectures, Fundamentals, and Applications, New Jersey: PrenticeHall, Inc., 1994. 